\title{
時刻選択モデルの選択肢区分が選択肢間の類似性及び不均一性に及ぼす影響* \\ Influences of Categorizing Alternatives in Time Choice Models \\ on Similarity and Non-identity Among Alternatives*
}

\author{
藤原章正 $^{* *} \cdot$ 神田佑亮 ${ }^{* * *} \cdot$ 杉惠頼寧 ${ }^{* * *} \cdot$ 岡村敏之 ${ }^{* * * *}$
}

By Akimasa FUJIWARA, Yusuke KANDA, Yoriyasu SUGIE and Toshiyuki OKAMURA

\section{1.はじめに}

ランダム効用最大化理論に基づく非集計多項ロジット (MNL)モデルでは，効用の誤差分布は選択肢間で独立か つ同一分布に従う (IID: Independent and Identical Distribution)という仮説を前提としている ${ }^{1)}$. この仮説に より，モデル式が極めてシンプルでかつ推定が容易であ るという特徴を持っており, 交通行動の離散選択問題の 分析に頻繁に適用されている. しかし，選択肢間に類似 性が存在したり，誤差分布に不均一性が存在したりする 場合にはこの IID 仮説が成立しないため, 推定結果にバ イアスが生じるという重大な問題点がある。

選択肢間の類似性や誤差分布の不均一性が無視できな い事例の 1 つとして, 「時刻」選択問題が考えられる. 時 刻選択問題では，個人はあるまとまった時間幅に基づい て判断を行ったり，また，アンケートで得られる回答值 では丸め誤差が存在するなどの理由から，連続量を離散 データにカテゴライズして MNL モデルに適用すること が少なくない，その際，時刻選択肢のカテゴライズがわ ずか数分違うだけで別々の選択肢として扱われる場合が 生じる. 従って, このような場合には隣り合う選択肢間 に類似性が全くないとは言えない，また，カテゴライズ の違いによって, 誤差分散が選択肢間で変動することも 予想される.

本研究では上記 2 つの問題を取り扱う。前者の問題を 考慮できる Paired Combinatorial Logit model(PCL モデル) と, 後者の問題を考慮できる Mass Point Logit model(MPL モデル)を用い，時刻のカテゴライズの違いが選択肢間の 類似性や不均一性に及ぼす影響について分析を行うこと を目的とする.

*キーワード : 交通行動分析, IID 仮説緩和, 時刻選択モデル

** 正会員, 工博 広島大学大学院国際協力研究科

（東広島市鏡山 1-5-1 TEL\&FAX: 0824-24-6921， E-mail:afujiw@hiroshima-u.ac.jp)

*** 学生員, 広島大学大学院国際協力研究科

(E-mail:wikiwiki@hiroshima-u.ac.jp)

**** 正会員, 工博 広島大学大学院国際協力研究科

(E-mail:ysugie@hiroshima-u.ac.jp)

***** 正会員, 工博 広島大学大学院国際協力研究科

(E-mail:tokamura@hiroshima-u.ac.jp)

\section{IID 仮説を緩和するアプローチのレビュー}

多項ロジットモデルの IID 仮説を緩和するために現在 まで多様な離散選択モデルが開発されてきた．大別する と効用誤差項の, i ) 類似性, 不均一性を考慮するモデル, ii )類似性を考慮するモデル, iii)不均一性を考慮するモデ ルに区分される.

\section{（1）類似性，不均一性を考慮するモデル}

誤差分散の制約がなく最も柔軟な構造を有するモデル として多項プロビット(MNP)モデル, Mixed Logit (MXL) モデル ${ }^{4)}$ が挙げられる(表 1). MNP モデルは誤差項の分散 に正規分布を仮定することにより導出され，選択肢間の 誤差相関の関係を全て考虑できる，選択肢数が増えたと きのパラメータ推定が複雑なことがあり適用は未だ困難 な部分があるが，最近になりモンテカルロシミュレーシ ヨン 5)をはじめとするパラメータ推定手法の開発が進み, さらに計算機速度の向上によりその適用可能性は高まっ てきている. また MXL モデルは, 説明変数のパラメー タがランダムに変動することを仮定したモデルである. $\eta$ の設定により類似性と不均一性を考慮することができ る点で, 誤差構造に最も柔軟に対応することが可能な口 ジットモデルと言える.

表 1．類似性，不均一性を考慮したモデル

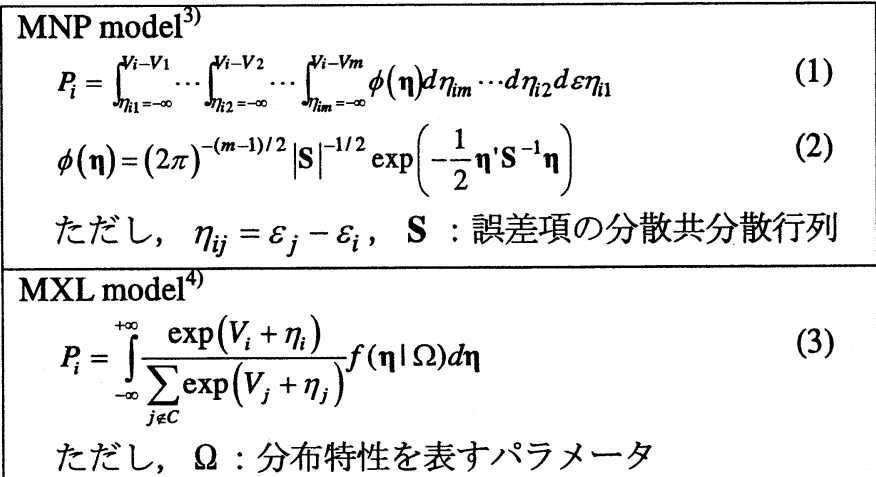

なお，個人を表す記述子 $n$ は省略する.

\section{（2）類似性を考慮するモデル}

誤差分散の非類似性仮説のみを緩和するモデルには, 代表的なものとして Nested Logit(NL)モデルや, PCL モデ ル, Cross Nested Logit(CNL)モデル ${ }^{6}$, Ordered Generalized Extreme Value (OGEV)モデルクなどが挙げられる(表 2). 
NL モデルは効用誤差の分散の大小を表現する logsum 変 数を導入することにより IIA 特性を緩和している. しか しながら, NL モデルでは同一のネスト内の選択肢間にお ける類似性は認めるものの, ネスト外の選択肢とは完全 に独立であると仮定している，選択文脈によってはネス 卜を越えて選択肢間に類似性が存在する場合が十分に考 えられ，このような場合には非現実的となる.これに対 して, 本研究で取り扱う PCL モデルは NL モデルと異な り，全ての選択肢ペア間の類似性をパラメータ $\sigma_{i j}$ として 扱うことが可能である.

\section{表 2．類似性を考慮したモデル群}

$$
\begin{array}{rl}
\text { NL model } & \\
P_{i} & =\frac{\exp \left(V_{i}\right)}{\sum_{r} \exp \left(V_{r}\right)} \cdot \frac{\exp \left(V_{r}+\lambda_{r} I_{r}\right)}{\sum_{s} \exp \left(V_{s}+\lambda_{s} I_{s}\right)} \\
I_{r} & =\ln \sum_{s} \exp \left(V_{s}\right) \\
\text { s.t. } 0 & 0<\lambda \leq 1
\end{array}
$$$$
\text { ここで， } \lambda: \text { ネスト内の類似性を示すパラメータ }
$$

PCL model ${ }^{2)}$

$$
\begin{aligned}
& P_{i}=\frac{\sum_{j \neq i}\left(\varpi_{i j}\right)\left\{\exp \left(\frac{V_{i}}{\varpi_{i j}}\right)+\exp \left(\frac{V_{j}}{\varpi_{i j}}\right)\right\}^{-\sigma_{i j}} \exp \left(\frac{V_{i}}{\varpi_{i j}}\right)}{\sum_{q=1}^{n-1} \sum_{r=q+1}^{n}\left(\varpi_{q r}\right)\left\{\exp \left(\frac{V_{q}}{\varpi_{q r}}\right)+\exp \left(\frac{V_{r}}{\varpi_{q r}}\right)\right\}^{\varpi_{q r}}} \\
& \varpi_{i j}=1-\sigma_{i j} \\
& \text { s.t. } 0 \leq \sigma_{i j}<1 \\
& \text { ここで, } \sigma \text { : 類似性を示すパラメータ }
\end{aligned}
$$

CNL model $^{6}$

$$
\begin{aligned}
& P_{i}=\sum_{a} \frac{\exp \left(\varpi_{a i}\right)\left\{\sum_{i} \exp \left(\varpi_{a i}\right)\right\}^{\lambda}}{\sum_{j} \exp \left(\varpi_{a j}\right) \sum_{b}\left\{\sum_{j} \exp \left(\varpi_{b j}\right)\right\}^{\lambda}} \\
& \varpi_{i j}=\left(\ln \alpha_{a i}-V_{i}\right) / \lambda
\end{aligned}
$$

s.t. $0<\lambda \leq 1, \quad 0 \leq \alpha_{a i} \leq 1, \quad \sum_{a} \alpha_{a i}=1$

ここで, $\lambda$ : ネスト内の類似性を示すパラメータ,

$\alpha$ : 選択肢があるネストに属する程度を示すパラメータ OGEV model ${ }^{\text {? }}$

$$
\begin{aligned}
& P_{i}=\sum_{r=i}^{i+M} \frac{w_{r-i} \exp \left(V_{i} / \lambda_{r}\right)}{\exp \left(I_{r}\right)} \cdot \frac{\exp \left(\lambda_{r} I_{r}\right)}{\sum_{s=1}^{J+M} \exp \left(\lambda_{s} I_{s}\right)} \\
& I_{r}=\ln \sum_{j} w_{r-j} \exp \left(V_{j}-\lambda_{r}\right) \\
& \text { s.t. } 0<\lambda \leq 1
\end{aligned}
$$

ここで, $\lambda$ : ネスト内の類似性を示すパラメータ, $w:$ 重みパラメータ

（3）不均一性を考慮するモデル

一方，誤差分散の均一性のみを緩和するアプローチか
ら導出されるモデルには, Heteroscadastic Extreme Value (HEV)モデル ${ }^{8,9}$, Mass Point Logit (MPL)モデル ${ }^{10)}$ 等があ る(表 3). HEV モデルは各選択肢の誤差項のスケールパラ メータ $\theta_{i}$ を推定する. 推定された $\theta_{i}$ の值が小さい選択肢 ほど，効用のばらつきが大きいこととなる，また，個人 の非観測異質性を考慮する MPL モデルは誤差項を非観 測異質性と真のランダム誤差に区分し, 前者の分布を離 散化したものである. 選択肢ごとに分布パラメータは可 変であることから, 誤差項の不均一性を考慮しているこ とになる. 杉惠ら ${ }^{10}$ は推定のし易いロジットモデルをべ 一スに改良を加え, 非観測異質性, すなわち不均一性を 考慮して IID 仮説を緩和した MPL モデルを構築し, 交通 機関選択問題に適用している.

表 3. 不均一性を考慮したモデル群

$$
\begin{aligned}
& \text { HEV model } \\
& P_{i}=\int_{-\infty}^{+\infty} \prod_{j \neq i, i \leq j \leq J} F\left[\theta_{j}\left(V_{i}-V_{j}+\varepsilon_{i}\right)\right] \theta_{i} f\left(\rho_{i} \varepsilon_{i}\right) d \varepsilon_{i} \\
& F[\theta \varepsilon]=\exp [-\exp (-\theta \varepsilon)] \\
& \text { ここで, } \theta: \text { スケールパラメータ }
\end{aligned}
$$

Mass Point Logit ${ }^{\text {(0) }}$

$$
P_{i}=\sum_{k=1}^{m}\left\{\frac{\prod_{i=1}^{J} \exp \left(V_{i}+\xi_{k i}\right)^{\delta_{i}}}{\sum_{j=1}^{J i} \exp \left(V_{j}+\xi_{k j}\right)}\right\} \rho_{k}
$$

s.t. $\sum_{k=1}^{m} \rho_{k}=1, \quad \rho_{k} \geq 0$

ここで, $\delta:$ 選択結果の識別ダミー, $m:$ mass point 数, $\xi_{k}, \rho_{k}: k$ 番目の Mass Point の位置と重みパラメータ

\section{3. 本研究で用いる川I 仮説を緩和したモデルの概要}

\section{（1）類似性を考慮するモデル：PCL モデル}

PCL モデルは選択肢のペアごとの類似性を考慮するこ とにより，MNL モデルの前提となる IID 仮説を緩和する モデルである． PCL モデルは一般的に用いられている NL モデルと同様に, 誤差分布を非独立かつ同一分布に従 うと仮定し，一般化極值分布に仮定した GEV モデルから 導出される ${ }^{11)}$.PCL モデルの一般式は(5)式のようになる.

ここで $P_{i}$ は選択肢 $i$ を選択する確率, $V_{i}$ は選択肢 $i$ の効 用を表す．PCL モデルは全ての選択肢間の類似性を表す パラメータ $\sigma$ を含んでいる. 類似性パラメータは $0 \leqq \sigma$ <1 の值をとり， $\sigma$ の值が 0 に近いほど選択肢の誤差は独 立であり， 1 に近くなるほど相関が大きいことを示す. 全ての $\sigma=0$ ならば, MNL モデルに帰着する.

また, NL モデルではデータに最も適したネスト構造を 分析者が事前に想定し，その検証を必要とするが，PCL モデルではこのような全てのペア間の類似性パラメータ の推定を行うことにより, NL モデルで必要であった構造 
の想定や検証を省略することが可能である.

（2）不均一性を考慮するモデル : MPL モデル

前述の通り MPL モデルは, MPL モデルの位置パラメ 一タと重みパラメータより選択肢別の誤差分散形を想定 することができる. Mass Point とは非観測異質性の連続分 布を分割し分布特性を表す離散化した点をいう．MPL モ デルはその連続的な分布を離散化してその影響を考慮す る手法であるため, 積分計算や近似計算を必要としない.

MPL モデルには仮説の違いにより 2 つの手法があるが, 本研究ではより一般性のある Lindsay 手法を用いること とする ${ }^{10)}$

\section{4. 会社到着時刻選択行動の分析}

\section{(1) 分析データの概要}

1997 年にフレックスタイム制度を導入した広島市内の 企業を対象にして出社行動の実態調查を行った ${ }^{12)}$. 本研 究で汇この調杳データを用いて出社時刻選択モデルを推 定する. 有効回答は 301 人であり, 抽出サンプルの $96.2 \%$ を占める. 出社時刻の質問ではあらかじめカテゴライズ された中から回答者が時間带を選ぶのではなく, 回答用 紙に直接時刻を記入してもらった，そのため出社時刻は 連続的なデータが得られており，離散選択モデルの目的 変量として使用するには次の作業が必要であった.

1 つ目は時刻のカテゴライズであり，図1で示す $3 つ$ のケースを想定する. 図 1 のケース $1 ， 2$ に示す，標準 始業時刻の 9:00 を基淮とし，時間幅を 40 分，60 分と異 なる場合と, ケース 3 に示す 60 分の時間幅であるが区切 りを9:30とした区分とした.いずれも 3 項選択モデルと なる.これはカテゴライズの違いによって選択肢間の誤 差分散の類似性や均一性に違いが生じるかどうか確認す るためである．時間の幅や回答の分布のピークの捉え方 が類似性に及ぼす影響を観測する目的である．カテゴラ イズの結果，選択肢別のサンプル数は表 4 に示すとおり となった。

2 つ目は代替選択肢に関する説明要因の水準值の補填 である．実際に出社した時間帯以外の時間帯について交 通サービス水準に関する情報が得られていないため, こ れらの情報を変数欠損データと考え，EM アルゴリズム 法の適用によってデータを補填した．EM アルゴリズム のより詳細な説明は参考論文 13）に委ねるが，基本的な 考え方は欠損データの期待值を有効データ相互の多重相 関関係から推定する統計手法である。

\section{(2) 集計分析}

図 2 に 10 分間隔の時間帯別の回答者数を示す. 平均会 社到着時刻は 8 時 56 分となり, その時刻前後に回答が集 中している.

図 3 に回答者の通勤交通手段と，世帯構成について集 計した結果を示す. 半数以上が自動車通勤を行っており,
公共交通利用者は 2 割程度である。.また, 全回答者の 8 割程度が世帯人数 2 人以上であり, 単身者は 2 割にすぎ ない. 図 4 に回答者の年龄と会社到着時刻のクロス集計 結果を示す. 出発時刻が遅くなるほど若年層の占める割 合が多い。

図 5 は回答者の通勤所要時間と会社到着時刻のクロス 集計結果を示している. 所要時刻が短い人ほど会社に遅 く到着する傾向にある．これは，通勤時間の短い人ほど 交通渋滞など遅れに対するリスクが少ないためであると 考えられる. 以上のことから, 会社到着時刻の選択には, これらの要因の影響を考慮する必要がある.

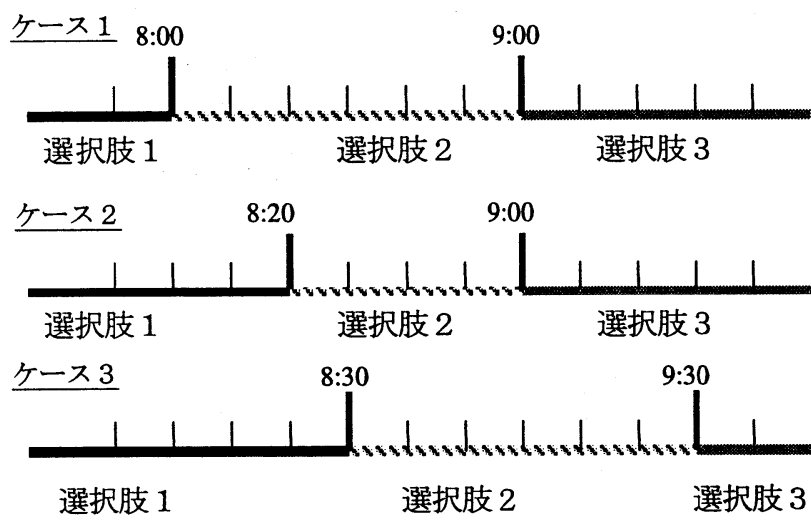

図 1. 出社時間帯選択肢のカテゴライズ

表 4. ケース別選択肢別有効サンプル数

\begin{tabular}{cccc}
\hline & 選択肢 1 & 選択肢 2 & 選択肢 3 \\
\hline ケース 14 & 14 人 & 167 人 & 120 人 \\
ケース 2 & 25 人 & 156 人 & 120 人 \\
ケース 3 & 57 人 & 228 人 & 16 人 \\
\hline
\end{tabular}

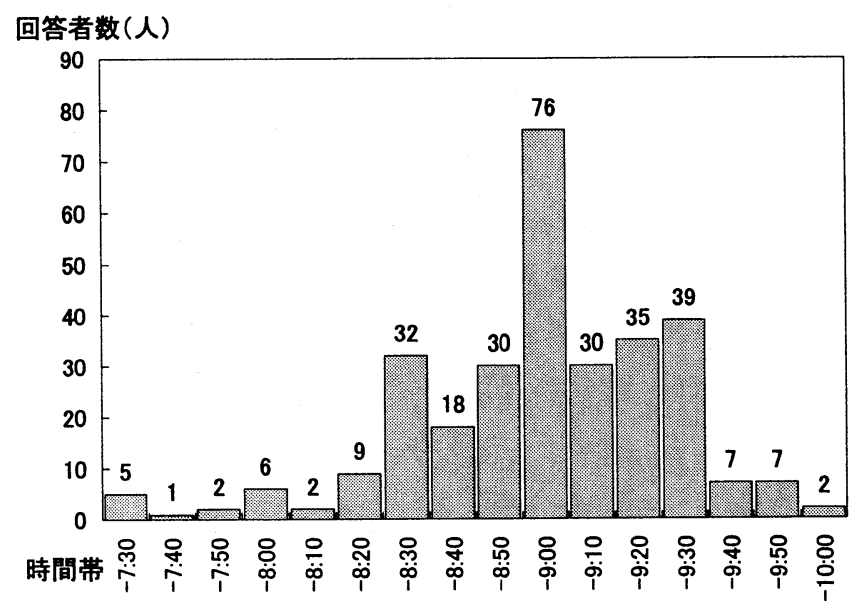

図 2. 会社到着時刻の分布

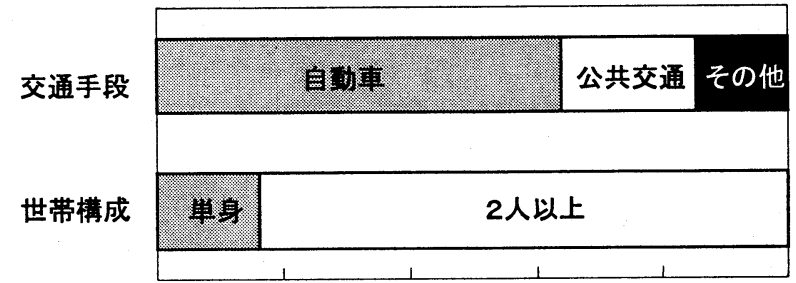

図 3. 回答者の通勤交通手段と世帯構成 


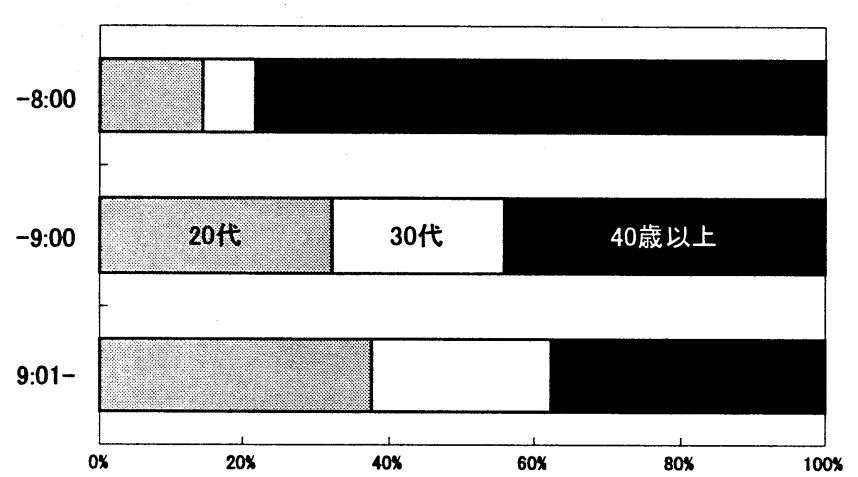

図 4. 年齢と会社到着時刻の関係

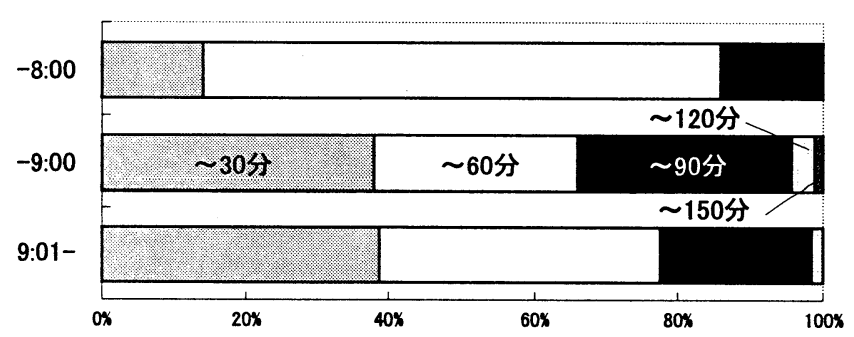

図 5. 通勤所要時間と会社到着時刻の関係

\section{5. 会社到着時刻選択モデルの推定}

上記の会社到着時刻データを用いて, 図 1 のケース 1 〜ケース 3 の各々のカテゴリーデータを内性変数とした PCL モデル，MPL モデルを推定する．得られた推定結果 をケース別, あるいはモデル間で比較することによって, 選択肢のカテゴライズが類似性および不均一性に及ぼす 影響について検討する.

表 5, 表 6, 表 7 に, それぞれ MNL モデル, PCL モ デル，MPL モデルを用いて推定した結果を示す.

\section{（1）類似性に及ぼす影響}

類似性の存在を確認するため, MNL モデル(表 5)と PCL モデル(表 6)を比較する. モデルの適合指標を尤度比によ り比較すると，わずかではあるが，全てのケースにおい て MNL モデルよりも向上している. 説明変数について は「公共交通」、「世帯構成」などの一部パラメータ推定 值の符号がケースにより変化している. これはカテゴラ イズにより，公共交通利用者や単身者が異なった選択肢 に属するためである.「所要時間」,「年齢」についてはカ テゴライズの違いによる影響は小さい.

PCL モデルの類似性パラメータに着目すると, ケース 1 のモデルでは全ての類似性パラメータが有意となった. また, そのケース 2,3 では 3 つうち 2 つのパラメー タが有意となった。 $\sigma_{13}$ （選択肢 1 と選択肢 3 の類似度） は全てのモデルにおいて有意水準 $1 \%$ で有意となってい る.これは両選択肢に共通の例えば車内混雑による不効 用や他の人との勤務時間のずれによる業務不効率性など といった, 省略変数の影響が作用していることを表して いる.

選択肢の時間幅の影響について検討しているケース 1 ， 2 に共通していえることは， $\sigma_{23}$ (選択肢 2 と選択肢 3 の 間) パラメータ推定値, $\mathrm{t}$ 值がともに大きいことである.
表 5. 会社到着時刻選択モデル(MNL モデル)

\begin{tabular}{|c|c|c|c|}
\hline 説明変数 & ケース 1 & ケース 2 & ケース 3 \\
\hline 所要時間（時間） & $\begin{array}{l}-0.485^{*} \\
(-2.311)\end{array}$ & $\begin{array}{l}-0.495^{*} \\
(-2.479)\end{array}$ & $\begin{array}{c}-0.494 \\
(-1.804)\end{array}$ \\
\hline $\begin{array}{l}\text { 自動車通勤ダミー } \\
\quad \text { (1: 自動車通勤者) }\end{array}$ & $\begin{array}{c}0.343 \\
(1.200)\end{array}$ & $\begin{array}{c}0.537 \\
(1.916)\end{array}$ & $\begin{array}{c}0.078 \\
(1.363)\end{array}$ \\
\hline 公共交通通勤ダミー & 0.329 & -0.050 & 0.174 \\
\hline （1：公共交通通勤者） & $(1.025)$ & $(-0.164)$ & $(0.492)$ \\
\hline 年齢（歳） & $\begin{array}{l}0.045^{*} \\
(2.065)\end{array}$ & $\begin{array}{l}0.078 \\
(4.360)\end{array}$ & $\begin{array}{l}0.041 \\
(3.120)\end{array}$ \\
\hline $\begin{array}{r}\text { 世帯構成ダミー } \\
\text { (1:単身者) }\end{array}$ & $\begin{array}{c}0.044 \\
(0.127)\end{array}$ & $\begin{array}{c}0.056 \\
(0.160)\end{array}$ & $\begin{array}{l}-0.453 \\
(-1.094)\end{array}$ \\
\hline 定数項 1 & $\begin{array}{l}4.290 \text { ** } \\
(3.522)\end{array}$ & $\begin{array}{l}5.149 \\
(5.897)\end{array}$ & $\begin{array}{l}3.050 \text { ** } \\
(5.265)\end{array}$ \\
\hline 定数項 2 & $\begin{array}{l}3.9077^{* *} \\
(3.184)\end{array}$ & $\begin{array}{l}4.720 * \\
(5.419)\end{array}$ & $\begin{array}{l}0.297 \\
(0.482)\end{array}$ \\
\hline 初期尤度 & -330.680 & -330.680 & -330.680 \\
\hline 最大尤度 & -244.348 & -259.324 & -197.010 \\
\hline 自由度調整尤度比 & 0.251 & 0.205 & 0.396 \\
\hline サンプル数 & 301 & 301 & 301 \\
\hline
\end{tabular}

表 6. 会社到着時刻選択モデル(PCL モデル)

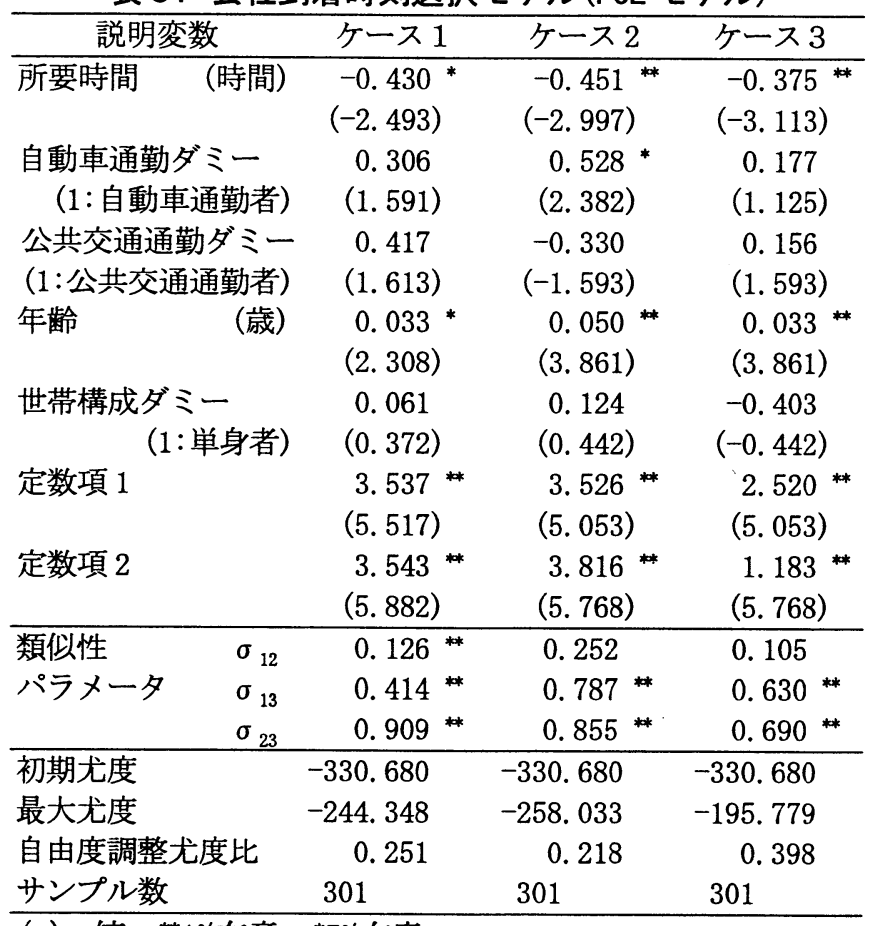

（）t 值， ${ }^{*} 1 \%$ 有意, ${ }^{*} 5 \%$ 有意

これは，回答者の回答時刻がこの $2 つ の$ 選択肢の境界付 近に集中しているためと考えられる．仮にカテゴリー区 分がわずか数分ずれたならば，選択肢の境界付近にある 多くの回答が他の選択肢に入る可能性がある.このこと からこの選択肢間の類似性が非常に強くなったものと考 えられる.また， $\sigma_{12}$ (選択肢 1 と選択肢 2 の類似度）の 推定值をケース 1 と 2 で比較すると, 選択肢 2 の時間幅 が小さくなるとパラメータ推定值は大きくなっている.

選択肢 2 の時間幅が小さくなることにより，それまで選 択肢 2 に属していた一部の個人が選択肢 1 に属すように 区分された結果，両選択肢間により強い類似性が現れた ものと考えられる. 
次に，選択肢の区切り位置が異なるケース 1 とケース 3 を比較する. 9:00 が基準のモデル（ケース 1）では, 選択肢が集中している付近の類似性パラメータ $\sigma_{23}$ の推 定值， $\mathrm{t}$ 值ともに非常に大きいが，一方，9:30 に区切り 位置があるケース 3 のモデルでは $\sigma_{23}$ の值は比較的小さ い.このことから，選択肢の境界付近に回答が集中して いる場合は類似性が強く現れやすいことを示している.

以上の結果から，選択肢のカテゴライズの仕方によっ て類似性の大きさが変化することが確認された. カテゴ ライズの仕方と類似性の大きさとの明確な関連づけは本 研究の少ないケーススタディではできないが, 時刻選択 モデルのような類似性問題の発生の可能性があるモデル 推定に当たっては PCL モデルの適用の必要性は高い.

\section{（2）不均一性に及ぼす影響}

表 7 に, 不均一性を考慮した Mass Point Logit モデル推 定結果を示す. 本研究では Mass Point 数を 2 として推定 計算を行った.これは予備的分析の結果 Mass Point 数が 2 以上になれば, 最終尤度関数值も推定值もほぼ一定值に 収束する傾向が見られたためである。

PCL モデル同様，モデルの尤度比を比較すると両モデ ルとも MNL モデルに比べ若干向上している. 説明変数 のパラメータに着目すると, PCL モデルの推定パラメー 夕と同様, 一部符号が逆転している傾向が見られる.

図6〜8にMass Point パラメータの重みパラメータ $\rho$, 位置パラメータ $゙$ から想定される選択肢別の誤差分散を 示している[1].ケース 1 およびケース 2 の位置パラメータ $\xi$ (図6および7)について着目すると，Mass Point 1 及び 2 の $\xi$ の間の距離が選択肢 2 と 3 では明らかに異なって いる. これは選択肢 2 の誤差分散の方が選択肢 3 の誤差 分散よりも大きいことを意味しており, 明らかに不均一 性が生じていることがわかる. 一方, ケース 3 (図 8)につ いて着目すると, 選択肢 2 と 3 の誤差分布の形状は似通 つており, 2 つの Mass Point $\xi$ 間の距離の違はほど等しく なっている. すなわち, ケース 3 では 2 つの選択肢の誤 差分散はほぼ均一であることを意味する.

これらのことから, 選択肢の時間幅や時間の区切り位 置が異なることにより, 誤差分布の分散形状にも違いが 生じることがわかった.

また，PCL モデル，MPL モデルおよび MNL モデルの 説明変数のパラメータ推定值を比較すると, 必ずしも等 価であるとはいえない，真のパラメータ值は不明なので 今の段階で PCL モデル, MPL モデルの優劣をつけること はできないが，少なくとも類似性，不均一性の存在がパ ラメータ推定にバイアスを生じさせている可能性がある と言えよう。

\section{6. おわりに}

本研究では誤差分散の特徵をパラメータで観測できる
表 7. 会社到着時刻選択モデル(MPL モデル)

\begin{tabular}{|c|c|c|c|c|}
\hline \multicolumn{2}{|c|}{ 説明変数 } & ケース 1 & ケース 2 & ケース 3 \\
\hline 所要時間 & (時間) & $\begin{array}{l}-0.936^{*} \\
(-2.493)\end{array}$ & $\begin{array}{l}-1.022 \\
(-2.208)\end{array}$ & $\begin{array}{l}-0.432 \\
(-0.838)\end{array}$ \\
\hline \multicolumn{2}{|c|}{ 自動車通勤ダミー } & $\begin{array}{c}0.292 \\
(0.596)\end{array}$ & $\begin{array}{c}0.642 \\
(1.446)\end{array}$ & $\begin{array}{c}0.345 \\
(0.469)\end{array}$ \\
\hline \multirow{2}{*}{\multicolumn{2}{|c|}{$\begin{array}{l}\text { 公共交通通勤ダミー } \\
\text { (1:公共交通通勤者) }\end{array}$}} & 0.249 & -0.351 & -0.945 \\
\hline & & $(0.413)$ & $(-0.413)$ & $(-0.829)$ \\
\hline 年齢 & （歳） & $\begin{array}{c}0.057 \\
(1.924)\end{array}$ & $\begin{array}{l}0.107^{* *} \\
(4.224)\end{array}$ & $\begin{array}{c}0.099^{*} \\
(2.154)\end{array}$ \\
\hline \multicolumn{2}{|c|}{ 世帯構成ダミー } & $\begin{array}{c}0.522 \\
(0.648) \\
\end{array}$ & $\begin{array}{c}0.676 \\
(0.829) \\
\end{array}$ & $\begin{array}{c}-1.271 \\
(-0.679) \\
\end{array}$ \\
\hline \multirow[t]{2}{*}{$\begin{array}{l}\text { Mass Point } \\
\text { パラメータ }\end{array}$} & $\rho_{1}$ & $\begin{array}{l}0.553^{*} \\
(2.382) \\
\end{array}$ & $\begin{array}{c}0.426 \\
(1.586) \\
\end{array}$ & $\begin{array}{l}0.798 \\
(9.510)\end{array}$ \\
\hline & $\begin{array}{l}\xi_{12} \\
\xi_{13} \\
\xi_{22} \\
\xi_{23}\end{array}$ & $\begin{array}{l}3.315 \\
4.384 \\
8.307 \\
5.536 \\
\end{array}$ & $\begin{array}{c}14.819^{* *} \\
11.668 \\
4.680 \\
5.809 \\
\end{array}$ & $\begin{array}{r}7.812 \\
11.668 \\
-0.629 \\
2.240 \\
\end{array}$ \\
\hline \multicolumn{2}{|l|}{ 初期尤度 } & -330.680 & -330.680 & -330.680 \\
\hline \multicolumn{2}{|c|}{ 最大尤度 } & -243.645 & -256.350 & -195.468 \\
\hline \multicolumn{2}{|c|}{ 自由度調整尤度比 } & 0.253 & $\begin{array}{l}0.224 \\
301\end{array}$ & $\begin{array}{l}0.401 \\
301\end{array}$ \\
\hline \multicolumn{2}{|l|}{ サンプル数 } & 301 & 301 & 301 \\
\hline
\end{tabular}

（ ） t 值, ${ }^{*}$ \% $\%$ 有意, ${ }^{*} 5 \%$ 有意

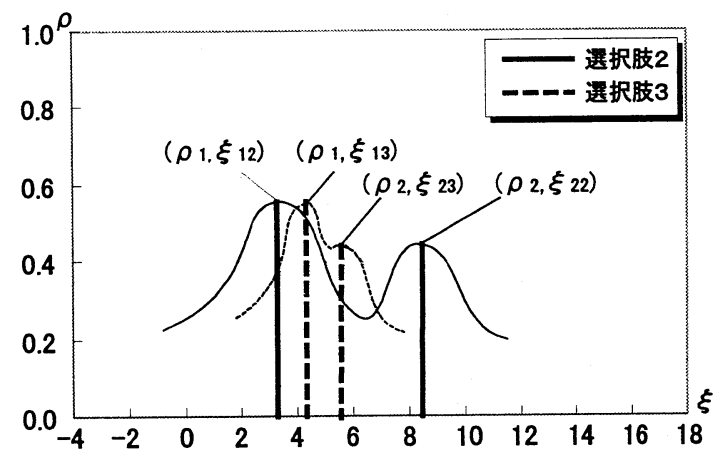

図 6. 選択肢別誤差分布の比較 (ケース 1)

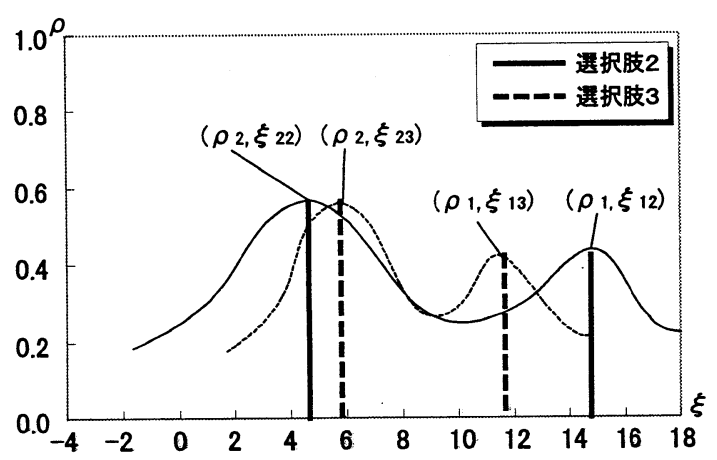

図 7. 選択肢別誤差分布の比較 (ケース 2)

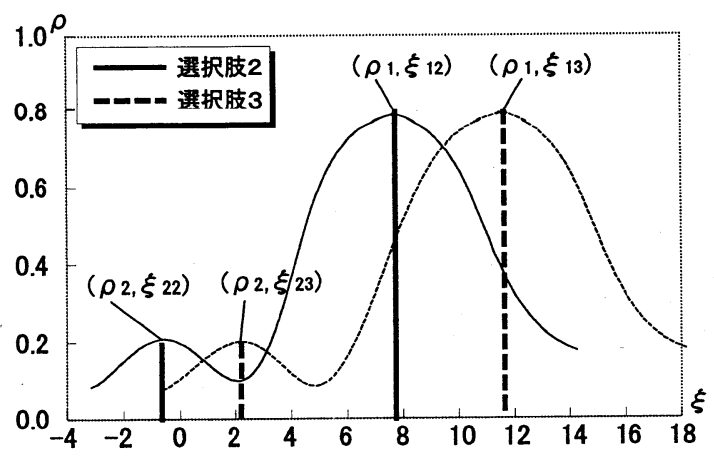

図 8．選択肢別誤差分布の比較 (ケース 3) 
PCL 及びMPL モデルを用いて, 時刻選択問題のような本 来連続量であるものを離散的に取り扱う場合の問題につ いて検討した. 分析の結果から，選択肢の時間幅や区切 り位置によって, 誤差分散の類似性および不均一性が共 に変化することが確認できた. また, 複数のケースを比 較することにより，選択肢のカテゴライズと誤差構造の 関係について観察することができた.

しかしながら，選択肢の分散特性を事前に予想した上 で時刻の選択肢をカテゴライズすることは, 至難であろ う．PCL モデルやMPL モデル，また MNP モデルのよう な IIA 特性緩和することが可能なモデルを適用すると, このような問題は回避することが可能となり, より不偏 性の高い推定ができる.この点は離散選択モデルの時刻 選択問題への適用可能性を大いに高める結果として評価 される.

\section{補注}

[1] 図 $6 \sim 8$ に示した誤差分布の形状は Mass Point パラ メータの推定值をもとに，2つの Mass Point を中心に 複合正規分布をすると仮定して概形を描いたものであ る.

\section{参考文献}

1) Bhat, C: Recent methodological advances relevant to activity and travel behavior analysis, Resource Paper presented for the $8^{\text {th }}$ Meeting of the IATBR, Austin, Texas, pp. 1-45, 1997

2) Chu, C.: A paired combinatorial logit model for travel demand analysis, Proceedings of $5^{\text {th }}$ WCTR, Vol.4, Yokohama, pp.295-309, 1989
3) Ben-Akiva, $M$ and Lerman, S: Discrete Choice Analysis, The MIT Press, pp.299-300, 1985

4) Brownstone, D. and Train, K.: Forecasting new product penetration with flexible substitution patterns, Journal of Econometrics, Vol. 89, pp.109-129, 1999

5) 例えば Maher M. et al.: Bias in discrete choice models estimates, Proceedings of ETC, Transportation Planning Methods, pp.1-12, 1999

6) Vovsha, $P$ and Bekhor, $S$ : The link-nested logit model of route choice: Overcoming the route overlapping problem, Paper Presented at $77^{\text {th }}$ TRB Annual Meeting, 1995

7) Small, K: A discrete choice model for ordered alternatives, Econometrica, Vol. 55, No.2, pp.409-424, 1987

8) Bhat, C: A heteroscedastic extreme value model of intercity travel mode choice, Transportation Research, Vol.29B, No.6, pp471-48, 1995

9) 福田, 森地: 観光目的地選択行動に対する精緻化さ れた個人選択モデルの適用可能性の検討, 土木計画 学研究講演集, No.22(2), pp.655-658, 1999

10）杉惠, 張, 藤原: 個人の異質性による交通機関選択 モデルの構造分析, 土木計画学研究論文集, No.12, pp.425-434, 1995

11) Koppeleman, F. and Wen, C.: The paired combinatorial logit model; Property estimation and application, Technical Paper, Department of Civil Engineering, Northwestern University, Evanton, Illinois, 1996

12）周藤, 杉惠, 藤原: フレックスタイム制度下におけ る通勤行動の時間的変化, 土木計画学研究論文集, No. 12, pp.655-662, 1998

13）藤原, 杉惠, 原田: 交通日誌データにおける無回答 バイアスの修正方法, 土木計画学研究論文集, No. 16, pp.61-64, 1999

\title{
時刻選択モデルの選択肢区分が選択肢間の類似性及び不均一性に及ぼす影響
}

\section{藤原章正・神田佑亮・杉惠頼寧・岡村敏之}

\begin{abstract}
本論文では, 時刻のカテゴライズの違いにより生ずる時間幅や区切り位置の違いが, 時刻選択モデルの推定 結果に及ぼす影響について検討する．交通需要予測として頻繁に用いられている多項ロジットモデルで前提 とする IID 仮説のうち, 誤差分散の独立性を緩和する PCL モデルと, 誤差分散の均一性を緩和する Mass Point Logit モデルを用いて分析を行う. 分析の結果から, 選択肢のカテゴライズによって, 誤差分散に類似性, 不 均一性の大きさが異なることが明らかとなった。
\end{abstract}

\section{Influences of Categorizing Alternatives in Time Choice Models on Similarity and Non-identity Among Alternatives} By Akimasa FUJIWARA, Yusuke KANDA, Yoriyasu SUGIE and Toshiyuki OKAMURA

This study aims at examining various categorized alternatives on the estimation results of time choice models. MNL models which are widely used in travel demand forecasting suppose that the error terms of utilities are independently and identically distributed. Paired Combinatorial Logit model and Mass Point Logit model are employed to relax the restrictive assumption of independence and identity respectively. The estimation results of these models revealed that the significance of similarity and non-identity among alternatives depends on time categories. 